Available online on 15.07.2020 at http://jddtonline.info
Open Access to Pharmaceutical and Medical Research

Open $\odot$ Access

Research Article

\title{
Is there an association between Anti-Citrullinated Peptide Antibodies and the Severity of Rheumatoid Arthritis Parameters in Algerian Patients?
}

\section{Siheme OUALI ${ }^{12^{*}}$, Khalida ZEMRI ${ }^{1}$, Feriel SELLAM ${ }^{6}$; Noria HARIR ${ }^{12}$, Zahira BENAISSA ${ }^{1}$, Sid Tadj HEBRI ${ }^{3}$, Ouassini BENSABER ${ }^{4}$, Douniazad ELMEHADJI ${ }^{1}$, Zouaoui NADJI ${ }^{3}$, Karima KAROUBI ${ }^{5}$}

1. Department of Biology, Djillali Liabes University of Sidi Bel Abbes, (Ex ITMA), Algeria

2. Laboratory of Molecular Microbiology, Proteomics and Health, Algeria

3. Department of Internal Medicine, CHU Sidi Bel Abbes, Algeria

4. Department of Functional Rehabilitation, CHU Sidi Bel Abbes, Algeria

5. Department of internal medicine, EPH Benisaf- AinTemouchent, Algeria

6. National Research Center of Biotechnology. CRBt, Algeria

\begin{abstract}
Objectives: The aim of this study was to demonstrate the relationships between anti-citrullinated peptide/protein antibodies status and clinical characteristics, disease severity, radiological damages and laboratory assessment in Algerian patients with Rheumatoid arthritis, as well as their importance like a predictive factor for the diagnosis of Rheumatoid arthritis (RA).

Methods: 281 patients diagnosed with RA according to ACR 1987 criteria in the internal medicine and Functional Rehabilitation departments (the University Hospital of Sidi Bel Abbes) were enrolled in the study based on medical records including age, gender, disease duration, disease activity score (DAS28), joint damages, laboratory tests and treatment. All data were processed and analyzed via SPSS 22.0.

Results: $86.5 \%$ of patients were females with a mean age and disease duration of respectively $52.665 \pm 12.3477,4.19 \pm 4.050$. Patients with AntiCCP positive $(79.7 \%)$ presented a high disease activity $(\mathrm{p}<\mathbf{0 . 0 0 0 1})$, a long disease duration $(\mathrm{p}=\mathbf{0 . 0 1 6})$ and a erosion damages $(\mathrm{p}<\mathbf{0 . 0 0 0 1})$. we did not found any significant relation between gender, hands damages and CRP..A logistic regression showed that the presence of Anti-CCP was associated with Erosion, disease activity, age and RF presence.
\end{abstract}

Conclusion: There was a strong relation between Anti-CCP antibodies status and the development of RA in Algerian patients. It could be considered as a useful predictor of disease severity.

Keywords: Rheumatoid Arthritis, Algerian Patients, Anti-Citrullinated Peptide/Protein Antibodies, Disease activity, Erosion, Severity.

Article Info: Received 11 April 2020; Review Completed 14 June 2020; Accepted 22 June 2020; Available online 15 July 2020

Cite this article as:

Ouali S, Zemri K, Sellam F, Harir N, Benaissa Z, Hebri ST, Bensaber O, Elmehadji D, Nadji Z, Karoubi K, Is there an association between Anti-Citrullinated Peptide Antibodies and the Severity of Rheumatoid Arthritis Parameters in Algerian Patients?, Journal of Drug Delivery and Therapeutics. 2020; 10(4):17-24 http://dx.doi.org/10.22270/jddt.v10i4.4201

\section{*Address for Correspondence:}

Siheme OUALI, PhD Candidate in Biochemistry-Immunology, Department of Biology, Djillali Liabes University of SidiBel Abbes, (Ex ITMA), Algeria

This article is distributed under the terms of the Creative Commons Attribution- NonCommercial 4.0 International License (http://creativecommons.org/licenses/by-nc/4.0/), which permits any noncommercial use, distribution, and reproduction in any medium, provided you give appropriate credit to the original author(s) and the source, provide a link to the Creative Commons license, and indicate if changes were made 


\section{INTRODUCTION:}

Rheumatoid arthritis (RA) is a chronic inflammatory joint disease and sometimes extra-articular, characterized by irreversible destruction of joints and bones, disability and los of function 1-2-3. With a prevalence of $0.5 \%$ among adults in Western countries, and $0.13 \%$ in north Africa (Algeria in particular $)^{4-5}$, reliable clinical research with the use of specific tests would be very useful for the early diagnosis of rheumatoid arthritis and therapeutic protocol ${ }^{6}$.

Several studies prove that anti-CCP (anti-citrullinated peptide/protein antibodies) and Rheumatoid Factors (RF), have been regarded as major factors in joint destruction? Anti-CCP is a more specific marker compared to RF, due to their high specificity to RA ${ }^{8}$.

Recently, the Anti-CCP became a major test of disease course, joints erosion, severity and early diagnosis ${ }^{9-10-11}$. It may be detectable before the onset of RA symptoms ${ }^{12}$, which proves their importance in the pathophysiology of RA ${ }^{13}$.Furthermore, Anti-CCP antibodies has been involved in criteria for ACR/EURL 2010 classification (the American College of Rheumatology/European League Against Rheumatism) ${ }^{14}$

The aim of this study was to investigate Anti-CCP status in western Algeria population and their association with clinical feature and medical managements (Disease activity, radiographic damages, erosion ...) of Algerian patients with RA.as well as their importance in the diagnosis of RA.

\section{PATIENTS AND METHODS:}

\section{The population:}

We carried out a cross study based on medical records over 281 patients with RA aged of 14 years or over; diagnosed between 2016 and 2019 at the level of Internal Medicine in partnership with Functional Rehabilitation Departments of the University Hospital of Sidi Bel Abbes.

Patients were diagnosed according to ACR 1987 criteria 15. The local Ethics Committee of University Hospital has approved our study.

We recorded the demographic characteristic such as: sex, age; and clinical and managements like: Disease duration, Disease activity score (DAS28) (running from 0 to 10), Erosion, Radiologic Joint damage, Laboratory assessment and Medication.

Concerning DAS28, the threshold values are over 5.1 for high activity, from 5.1 to 3.2 for moderate activity, between 3.2 and 2.6 for low activity and less than 2.6 for remission 16 .

\section{Statistical Analysis:}

Patients' characteristics were presented as means and standard deviation for continuous variables and as frequencies and percentages for categorical variables.

For descriptive analysis we present the results as Mean \pm standard deviation and frequency (\%). For the cross study, the categorical variables were tested using Pearson's $\mathrm{Khi}^{2}$ test $\left(\chi^{2}\right)$ and $\mathrm{T}$ test for continuous variables. Logistic regression was used to estimate the independent effects of some RA characteristics on the presence of anti-CCP.

All data were processed and analyzed via SPSS 22.0 (Statistical Package for the Social Sciences, IBM Corporation; Chicago, IL. August 2013).The level of significance was $<5 \%$

\section{RESULTS:}

A total of 281 patients with rheumatoid arthritis were included in our cross study $(86.5 \%$ were women ; females/males ratio 7.3947 ), the mean age was of $52.665 \pm 12.3477$ ( range 14-80); The most affected age group was $\geq 46$ years with a rate of $74.4 \%, 8.2 \%$ of males were smokers, More than half of our patients were affected in hands joints $(68.3 \%)$ followed by wrists $(60.1 \%)$.The mean disease duration and DAS28 of the enrolled participants were $4.19 \pm 4.050$ and $4.5128 \pm 1.23452$ respectively. Concerning the disease activity, $1.1 \%$ of patients in the remission status, $13.5 \%$ with a low activity, $54.4 \%$ with a moderate activity and $31 \%$ with a high activity. Positive anticcp and RF were noted in $79.7 \%$ and $80.4 \%$ of patients respectively (Table 1 ).

Table 2 demonstrate a comparison of various factors such as gender; age; disease duration; erosion; tobacco status; joint damage; ESR; CRP and medication in two rheumatoid arthritis groups (positive and negative Anti-CCP groups).We noted a high signification between the erosion; DAS 28, high activity ; shoulders joints and the positive Anti-CCP group $(\mathrm{p}=<0.0001)$. We reported also a signification between AntiCCp status and tobacco $(p=0.047)$, ESR ( $p=0.001)$, Methotrexate use ( $\mathrm{p}=0.003)$.

Table 03 indicates an analysis of the characteristics of RA such as age; DAS28, joint damage, erosion, ESR in accordance with RF and Anti-CCP status.

We noticed a mutual association of Anti-CCP rate with DAS28 (Figure 1) and Disease duration (Figure 2)

The Binary logistic regression illustrated that the Anti-CCP status was significantly associated with age; disease duration; DAS28; ESR and RF (Table 4). 


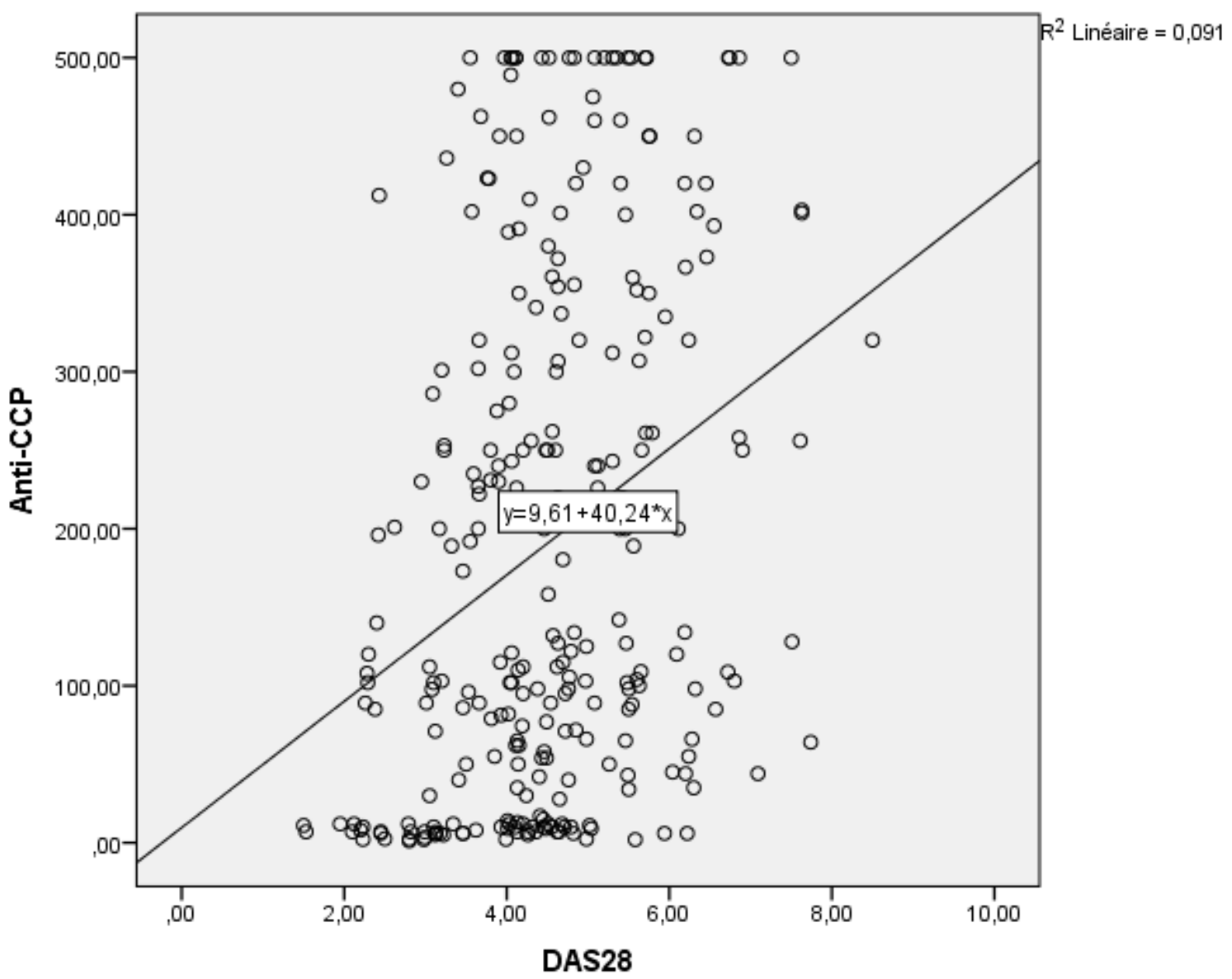

Figure 1: linear correlation between Anti-CCP titer and disease activity score (DAS28)

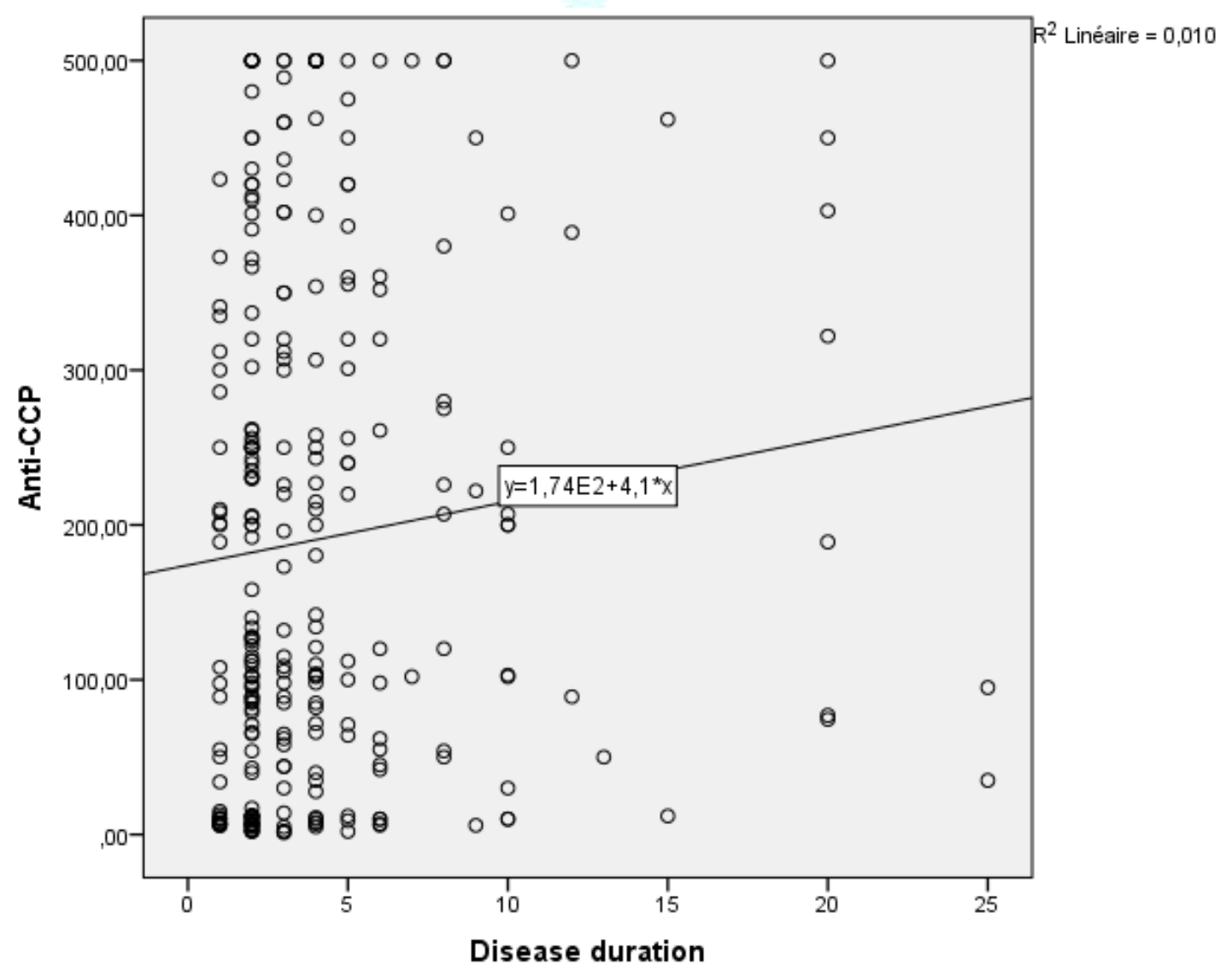

Figure 2: linear correlation between Anti-CCP titer and Disease duration 
Table 1 : Charactéristics of RA patients

\begin{tabular}{|c|c|}
\hline Characteristics (Mean \pm SD) or $n(\%)$ & Rheumatoid arthritis $n=281$ \\
\hline Female gender & $243(86.5 \%)$ \\
\hline Age (years) & $52.665 \pm 12.3477$ \\
\hline$\leq 45$ & $72(25.6 \%)$ \\
\hline$\geq 46$ & $209(74.4 \%)$ \\
\hline Disease duration (years) & $4.19 \pm 4.050$ \\
\hline \multicolumn{2}{|l|}{ Comorbidity } \\
\hline Type 2 diabetes & $40(14.2 \%)$ \\
\hline Hypertension & $114(40.6 \%)$ \\
\hline active tobacco (males) & $23(8.2 \%)$ \\
\hline \multicolumn{2}{|l|}{ Radiologic Joint damage } \\
\hline Hands & $192(68.3 \%)$ \\
\hline Wrists & $169(60.1 \%)$ \\
\hline Knees & $158(56.2 \%)$ \\
\hline Elbows & $109(38.8 \%)$ \\
\hline Shoulders & $100(35.6 \%)$ \\
\hline Feet & $86(30.6 \%)$ \\
\hline Ankle & $44(15.7 \%)$ \\
\hline Erosion & $67(23.8 \%)$ \\
\hline DAS28 & $4.5128 \pm 1.23452$ \\
\hline \multicolumn{2}{|l|}{ Disease activity } \\
\hline Remission & $3(1.1 \%)$ \\
\hline Low & $38(13.5 \%)$ \\
\hline Moderate & $153(54.4 \%)$ \\
\hline High & $87(31 \%)$ \\
\hline Anti-CCP titer (Ul/ml) & $191.1977 \pm 164.87025$ \\
\hline Positive Anti-CCP & $224(79.7 \%)$ \\
\hline RF titer (Ul/ml) & $68.5438 \pm 76.30074$ \\
\hline Positive RF & $226(80.4 \%)$ \\
\hline ESR titer $(\mathrm{mm} / \mathrm{h})$ & $43.434 \pm 24.8095$ \\
\hline Accelerated ESR & $230(81.9 \%)$ \\
\hline CRP titer & $17.9390 \pm 28.69422$ \\
\hline Positive CRP & $184(65.5 \%)$ \\
\hline \multicolumn{2}{|l|}{ Medication } \\
\hline Methotrexate & $226(80.4 \%)$ \\
\hline leflunomide & $45(16 \%)$ \\
\hline Hydroxychloroquine & $4(1.4 \%)$ \\
\hline Glucocorticoid & $159(56.6 \%)$ \\
\hline
\end{tabular}


Table 2: Data based on Anti-CCP status in RA patients

\begin{tabular}{|c|c|c|c|}
\hline \multirow[t]{2}{*}{ Characteristics n(\%) } & \multicolumn{2}{|c|}{ RA patients $n=281$} & \multirow[b]{2}{*}{$P$ value } \\
\hline & $\begin{array}{c}\text { Positive Anti-CCP } \\
n=224\end{array}$ & $\begin{array}{c}\text { Negative Anti-CCP } \\
n=57\end{array}$ & \\
\hline Female gender & $32(11.39 \%)$ & $6(2.14 \%)$ & 0.459 \\
\hline Age (years) & $51.192 \pm 12.940$ & $58.456 \pm 11.2870$ & $<0.0001$ \\
\hline Disease duration (years) & $4.48 \pm 4.280$ & $3.04 \pm 2.712$ & 0.016 \\
\hline Erosion & $64(22.78 \%)$ & $3(1.07 \%)$ & $<0.0001$ \\
\hline Active tobacco (males) & $22(7.83 \%)$ & $1(0.36 \%)$ & 0.047 \\
\hline \multicolumn{4}{|l|}{ Disease activity } \\
\hline Remission & $1(0.36 \%)$ & $2(0.71 \%)$ & 0.045 \\
\hline Low & $18(6.41 \%)$ & $20(7.12 \%)$ & $<0.0001$ \\
\hline Moderate & $123(43.77 \%)$ & $30(10.68 \%)$ & 0.758 \\
\hline High & $82(29.18 \%)$ & $5(1.78 \%)$ & $<0.0001$ \\
\hline DAS28 & $4.7166 \pm 1.19056$ & $3.7119 \pm 1.07554$ & $<0.0001$ \\
\hline \multicolumn{4}{|l|}{ Joint damage } \\
\hline Hands & $158(56.23 \%)$ & $34(12.10 \%)$ & 0.115 \\
\hline Wrists & $144(51.25 \%)$ & $25(8.90 \%)$ & 0.005 \\
\hline Knees & $126(44.84 \%)$ & $32(11.39 \%)$ & 0.988 \\
\hline Elbows & $94(33.45 \%)$ & $15(5.34 \%)$ & 0.030 \\
\hline Shoulders & $93(33.10 \%)$ & $7(2.49 \%)$ & $<0.0001$ \\
\hline Feet & $71(25.27 \%)$ & $15(5.34 \%)$ & 0.431 \\
\hline Ankle & $39(13.88 \%)$ & $5(1.78 \%)$ & 0.109 \\
\hline \multicolumn{4}{|l|}{ Laboratory assessment } \\
\hline $\mathrm{ESR}(\mathrm{mm} / \mathrm{h})$ & $45.875 \pm 25.0779$ & $33.842 \pm 21.3473$ & 0.001 \\
\hline CRP (Ul/ml) & $19.0826 \pm 31.27544$ & $13.4451 \pm 13.99490$ & 0.186 \\
\hline \multicolumn{4}{|l|}{ Drugs use } \\
\hline Methotrexate & $188(66.90 \%)$ & $38(13.52 \%)$ & 0.003 \\
\hline leflunomide & $35(12.46 \%)$ & $10(3.56 \%)$ & 0.724 \\
\hline Hydroxychloroquine & $3(1.07 \%)$ & $1(0.36 \%)$ & 0.813 \\
\hline Glucocorticoid & $132(46.98 \%)$ & $27(9.61 \%)$ & 0.116 \\
\hline
\end{tabular}


Table 3: Charactiristics of RA patients according to Anti-CCP and RF status.

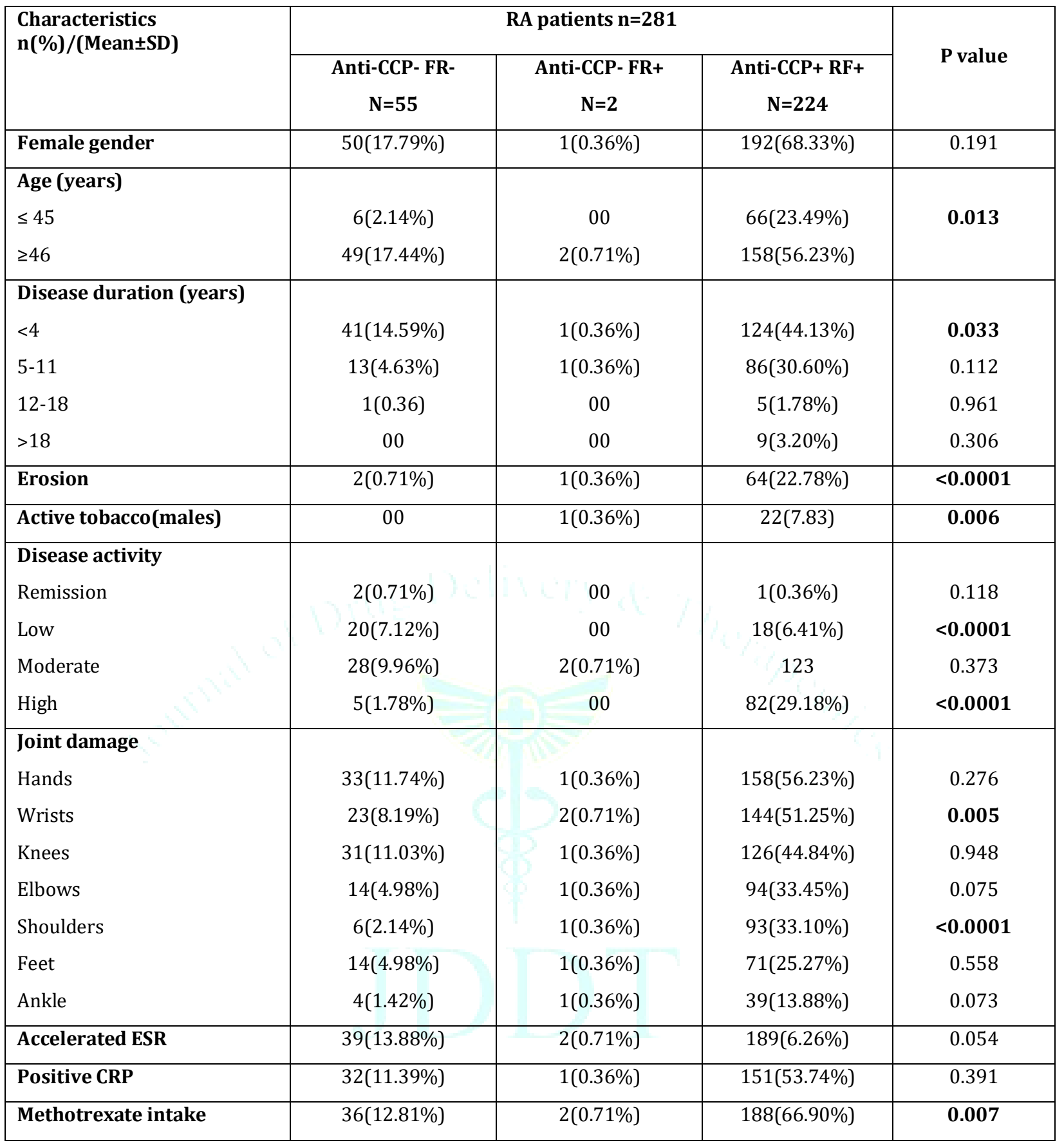

Table 4: Binary regression for the presence of Anti-CCP

\begin{tabular}{|l|c|c|c|}
\hline \multirow{2}{*}{ Factors } & \multicolumn{3}{|c|}{ RA Patients n= 281 } \\
\cline { 2 - 4 } & $\mathbf{0 R}$ & $\mathbf{9 5 \%}$ IC & P value \\
\hline Age (years) & 0.945 & $0,919-0.973$ & $\mathbf{0 . 0 0 0 1}$ \\
\hline Disease duration (years) & 1.159 & $1.023-1.313$ & $\mathbf{0 . 0 2 1}$ \\
\hline DAS28 & 2.230 & $1.648-3.017$ & $\mathbf{0 . 0 0 0 1}$ \\
\hline ESR(mm/h) & 1.024 & $1.009-1.039$ & $\mathbf{0 . 0 0 1}$ \\
\hline CRP (Ul/ml) & 1.014 & $0.995-1.034$ & 0.146 \\
\hline RF (Ul/ml) & 1.158 & $1.112-1.206$ & $<\mathbf{0 . 0 0 0 1}$ \\
\hline
\end{tabular}




\section{DISCUSSION:}

Positive anti-CCP status is primarily associated with bone loss, disability, disease duration and disease activity in RA patients 17. Our cross study showed this relationship between clinical characteristics, disease activity, joints damages and Anti-CCP status in Algerian RA patient from western Algeria (Sidi Bel Abbes region in particular).

BARRA.L et al illustrated that positive Anti-CCP group were younger $(p<0.0001)$ with a longer disease duration 18 . Moreover, ARNAB.B et al, reported a similar results regarding the duration of the disease and Anti-CCP $(p=0.003)$ 19. Orsolini. G et al 20 reported as well a correlation between disease duration and Anti-CCP status $(\mathrm{p}=0.014)$. Anti-CCP negative patients were older with less disease activity 21 .

There is a strong association between anti-CCPs and radiological joints damages 22 . Ghozlani et al 23 confirm the influence of anti-CCPs status on radiological erosion $(p=0.001)$. Furthermore. Yang et $\mathrm{al}^{24}$ noted a high correlation between Anti-CCP positive and sever joint damage $(<0.005)$.Another study by $\mathrm{Im}$ et $\mathrm{al}^{13}$ showed a significant association between erosion and Anti-CCP positive $(\mathrm{p}=0.0024)$. Barra et al 18 conclude the same result in 160 patients $(\mathrm{p}=0.0058)$. However, the results of Slimani et al 21 disagreed with previous investigations, they did not find any relation between erosion and Anti-CCP status.

In RA there is a significant association between RF, anti-ccp and disease severity ${ }^{23-25}$. However, patients positive for antiCCPand RF both had a high risk of disease progression 26 . In addition, Forslind et al. ${ }^{22}$ show that anti-CCP appeared to be an important predictor in early RA. Nonetheless, Barra et al 18 did not find any significant association between RF positivity and erosive disease.

A significant relation between radiologic assessment of wrist, hands and positive Anti-CCP was observed in the Serdaroğlu et al data 27 . In our investigation we found a significant correlation between wrist radiologic damages and positive Anti-CCP patients ( $\mathrm{p}=0.005)$

According to another investigation 28-29-30-31. Our study demonstrate a high association between Anti-CCP status and DAS28 $(\mathrm{p}<\mathbf{0 . 0 0 0 1})$. These results were in contradiction with some studies from Tunisia, Thailand, Egypt and Italy 25-30-3220 .

There was no significant correlation between the analyses of laboratory assessment and positive Anti-CCP23-33-18-27, many studies disagreed with this investigation 19-21-22-34-35, they found a high significant relation between ESR and Anti-CCP status similar to our results $(\mathrm{p}=0.001)$.

Smoking increases the high secretion of anti-CCP antibodies in RA patients with shared epitope ${ }^{36-37}$. Forslind et al 22 , García de Veas Silva et al 38 reported a high significant association between Anti-CCP status and smoking. Our data demonstrate a significant association $(p=0.047)$. Other studies 18-20 were paradoxical with previous results that showed no significant difference between tobacco status and positive Anti-CCP.

Likewise, The most common received drug in our data was Methotrexate with a significant different with Positive AntiCCP patients ( $p=0.003)$. Nevertheless, some studies did not find any correlation between Methorexate use and Anti-CCP positive $18-21$

\section{CONCLUSION:}

Our data showed that Algerian RA patients with positive Anti-CCP antibodies have an active high disease activity and long disease duration. Anti-CCP was considered as a predicator factor for, radiologic erosion joint progression and as prognostic factor of RA to predict the course of disease activity and the effectiveness of the treatment Further studies on larger numbers of patients are needed to confirm our findings.

\section{Acknowledgements:}

We would like to thank the patients for their participation and staff at the Internal Medicine of the Departments of Internal Medicine and Functional Rehabilitation of the University Hospital of Sidi-bel-Abbes for their invaluable support, guidance, and educational insight.

\section{Conflict of interest:}

The authors declare no conflicts of interest

\section{REFERENCES}

1. American College of Rheumatology Subcommittee on Rheumatoid Arthritis Guidelines. Guidelines for the management of rheumatoid arthritis: 2002 Update. Arthritis \& Rheumatism, 2002; 46(2):328-46.

2. Tobón GJ, Youinou P, Saraux A. The environment, geoepidemiology, and autoimmune disease: Rheumatoid arthritis. Journal of Autoimmunity, 2010; 35(1):10-4.

3. Avouac J. Diagnostic and predictive value of anti-cyclic citrullinated protein antibodies in rheumatoid arthritis: a systematic literature review. Annals of the Rheumatic Diseases, 2005; 65(7):845-51.

4. Alamanos Y, Voulgari PV, Drosos AA. Incidence and Prevalence of Rheumatoid Arthritis, Based on the 1987 American College of Rheumatology Criteria: A Systematic Review. Seminars in Arthritis and Rheumatism, 2006; 36(3):182-8.

5. Slimani S, Ladjouze-Rezig A. Prevalence of rheumatoid arthritis in an urban population of Algeria: a prospective study. Rheumatology, 2014; 53(3):571-3.

6. Kirwan JR, Quilty B. Prognostic criteria in rheumatoid arthritis: can we predict which patients will require specific antirheumatoid treatment? Clin Exp Rheumatol, 1997; 15 Suppl 17:S15-25

7. Haugeberg G, Bøyesen P, Helgetveit K, Prøven A. Clinical and Radiographic Outcomes in Patients Diagnosed with Early Rheumatoid Arthritis in the First Years of the Biologic Treatment Era: A 10-year Prospective Observational Study. J Rheumatol, 2015; 42(12):2279-87.

8. Nishimura K, Sugiyama D, Kogata Y, Tsuji G, Nakazawa T, Kawano S, et al. Meta-analysis: Diagnostic Accuracy of AntiCyclic Citrullinated Peptide Antibody and Rheumatoid Factor for Rheumatoid Arthritis. Ann Intern Med, 2007; 146(11):797.

9. Svärd A, Kastbom A, Reckner-Olsson Å, Skogh T. Presence and utility of IgA-class antibodies to cyclic citrullinated peptides in early rheumatoid arthritis: the Swedish TIRA project. Arthritis Res Ther, 2008; 10(4):R75.

10. van Venrooij WJ, Zendman AJW, Pruijn GJM. Autoantibodies to citrullinated antigens in (early) rheumatoid arthritis. Autoimmunity Reviews, 2006; 6(1):37-41.

11. van Gaalen FA, Linn-Rasker SP, van Venrooij WJ, de Jong BA, Breedveld FC, Verweij CL, et al. Autoantibodies to cyclic citrullinated peptides predict progression to rheumatoid arthritis in patients with undifferentiated arthritis: A prospective cohort study. Arthritis \& Rheumatism, 2004; 50(3):709-15.

12. Rantapää-Dahlqvist S, de Jong BAW, Berglin E, Hallmans G, Wadell G, Stenlund $\mathrm{H}$, et al. Antibodies against cyclic citrullinated peptide and IgA rheumatoid factor predict the development of rheumatoid arthritis: Anti-CCP Antibody and IgA-RF Predict RA. Arthritis \& Rheumatism, 2003; 48(10):2741-9. 
13. Im CH, Kang EH, Ryu HJ, Lee JH, Lee EY, Lee YJ, et al. Anti-cyclic citrullinated peptide antibody is associated with radiographic erosion in rheumatoid arthritis independently of shared epitope status. Rheumatol Int, 2009; 29(3):251-6.

14. Aletaha D, Neogi T, Silman AJ, Funovits J, Felson DT, Bingham CO, et al. 2010 Rheumatoid arthritis classification criteria: an American College of Rheumatology/European League Against Rheumatism collaborative initiative. Arthritis Rheum, 2010; 62(9):2569-81.

15. Saraux A, Berthelot JM, Chalès G, Le Henaff $C$, Thorel JB, Hoang $S$, et al. Ability of the American College of Rheumatology 1987 criteria to predict rheumatoid arthritis in patients with early arthritis and classification of these patients two years later. Arthritis Rheum, 2001; 44(11):2485-91.

16. Prevoo MLL, Van'T Hof MA, Kuper HH, Van Leeuwen MA, Van De Putte LBA, Van Riel PLCM. Modified disease activity scores that include twenty-eight-joint counts development and validation in a prospective longitudinal study of patients with rheumatoid arthritis: MODIFIED DISEASE ACTIVITY SCORE. Arthritis \& Rheumatism, 1995; 38(1):44-8.

17. Cheng T-T, Yu S-F, Su F-M, Chen Y-C, Su BY-J, Chiu W-C, et al. Anti-CCP-positive patients with RA have a higher 10-year probability of fracture evaluated by FRAX®: a registry study of RA with osteoporosis/fracture. Arthritis Research \& Therapy, 2018; 20(1):16.

18. Barra L, Bykerk V, Pope JE, Haraoui BP, Hitchon CA, Thorne JC, et al. Anticitrullinated protein antibodies and rheumatoid factor fluctuate in early inflammatory arthritis and do not predict clinical outcomes. J Rheumatol, 2013; 40(8):1259-67.

19. Arnab B, Biswadip G, Arindam P, Shyamash M, Anirban G, Rajan P. Anti-CCP antibody in patients with established rheumatoid arthritis: Does it predict adverse cardiovascular profile? J Cardiovasc Dis Res, 2013;4(2):102-6.

20. Orsolini G, Caimmi C, Viapiana O, Idolazzi L, Fracassi E, Gatti D, et al. Titer-Dependent Effect of Anti-Citrullinated Protein Antibodies On Systemic Bone Mass in Rheumatoid Arthritis Patients. Calcif Tissue Int, 2017; 101(1):17-23.

21. Slimani S, Abbas A, Ben Ammar A, Kebaili D, Ali EH, Rahal F, et al. Characteristics of rheumatoid arthritis in Algeria: a multicenter study. Rheumatol Int, 2014; 34(9):1235-9.

22. Forslind K, Ahlmén M, Eberhardt K, Hafström I, Svensson B, BARFOT Study Group. Prediction of radiological outcome in early rheumatoid arthritis in clinical practice: role of antibodies to citrullinated peptides (anti-CCP). Ann Rheum Dis, 2004; 63(9):1090-5.

23. Ghozlani I, Mounach A, Ghazi M, Kherrab A, Niamane R, El Maghraoui A. Influence of anti-cyclic citrullinated peptide on disease activity, structural severity, and bone loss in Moroccan women with rheumatoid arthritis. The Egyptian Rheumatologist, 2018; 40(2):73-8.

24. Kim HH, Kim J, Park S-H, Kim S-K, Kim O-D, Choe J-Y. Correlation of anti-cyclic citrullinated antibody with hand joint erosion score in rheumatoid arthritis patients. Korean J Intern Med, 2010; 25(2):201-6.

25. $\mathrm{Mb} \mathrm{H}, \mathrm{S} \mathrm{M}, \mathrm{N} \mathrm{K}, \mathrm{H} \mathrm{M}, \mathrm{F} \mathrm{F}, \mathrm{A}$ R, et al. Anticyclic citrullinated peptide antibody and rheumatoid factor in south Tunisian patients with rheumatoid arthritis: association with disease activity and severity. J Clin Lab Anal, 2013; 28(1):21-6.
26. Syversen SW, Gaarder PI, Goll GL, Ødegård S, Haavardsholm EA, Mowinckel P, et al. High anti-cyclic citrullinated peptide levels and an algorithm of four variables predict radiographic progression in patients with rheumatoid arthritis: results from a 10-year longitudinal study. Ann Rheum Dis, 2008; 67(2):212-7.

27. Serdaroğlu M, Çakırbay H, Değer O, Cengiz S, Kul S. The association of anti-CCP antibodies with disease activity in rheumatoid arthritis. Rheumatol Int, 2008; 28(10):965-70.

28. Bodur H, Ataman S, Akbulut L, Evcik D, Kavuncu V, Kaya T, et al. Characteristics and medical management of patients with rheumatoid arthritis and ankylosing spondylitis. Clin Rheumatol, 2008; 27(9):1119-25.

29. Önder B, Kurtaran A, Kimyon S, Selçuk B, Akyüz M. Association of anti-CCP positivity with serum ferritin and DAS-28. Rheumatol Int, 2009; 30(2):223-7.

30. Vanichapuntu M, Phuekfon P, Suwannalai P, Verasertniyom O, Nantiruj K, Janwityanujit S. Are anti-citrulline autoantibodies better serum markers for rheumatoid arthritis than rheumatoid factor in Thai population? Rheumatol Int, 2010; 30(6):755-9.

31. Alexiou I, Germenis A, Ziogas A, Theodoridou K, Sakkas LI. Diagnostic value of anti-cyclic citrullinated peptide antibodies in Greek patients with rheumatoid arthritis. BMC Musculoskelet Disord, 2007; 8(1):37.

32. Abdel-Nasser AM, Mahmoud MH, El Mansoury TM, Osman AM. Anti-CCP2 is an adjunct to, not a surrogate for, rheumatoid factor in the diagnosis of rheumatoid arthritis: diagnostic utility of anti-CCP2 antibodies in Egyptian patients with rheumatoid arthritis. Scandinavian Journal of Rheumatology, 2008; 37(5):329-36.

33. Shovman O, Gilburd B, Zandman-Goddard G, Sherer Y, Orbach H, Gerli R, et al. The Diagnostic Utility of Anti-cyclic Citrullinated Peptide Antibodies, Matrix Metalloproteinase-3, Rheumatoid Factor, Erythrocyte Sedimentation Rate, and C-reactive Protein in Patients with Erosive and Non-erosive Rheumatoid Arthritis. Clinical and Developmental Immunology, 2005; 12(3):197-202.

34. bn Yacoub, Y., Amine, B., Laatiris, A. et al. Rheumatoid factor and antibodies against citrullinated peptides in Moroccan patients with rheumatoid arthritis: association with disease parameters and quality of life. Clin Rheumato, 2012; 31:329-334.

35. González-Febles J, Rodríguez-Lozano B, Sánchez-Piedra C, Garnier-Rodríguez J, Bustabad S, Hernández-González M, et al. Association between periodontitis and anti-citrullinated protein antibodies in rheumatoid arthritis patients: a cross-sectional study. Arthritis Res Ther, 2020; 22(1):27.

36. Linn-Rasker SP. Smoking is a risk factor for anti-CCP antibodies only in rheumatoid arthritis patients who carry HLA-DRB1 shared epitope alleles. Annals of the Rheumatic Diseases, 2006; 65(3):366-71.

37. Van Doornum S, McColl G, Wicks IP. Accelerated atherosclerosis: An extraarticular feature of rheumatoid arthritis? Arthritis \& Rheumatism, 2002; 46(4):862-73.

38. García de Veas Silva JL, González Rodríguez C, Hernández Cruz B. Asociación del epítopo compartido, el tabaquismo y la interacción entre ambos con la presencia de autoanticuerpos (anti-PCC y FR) en pacientes con artritis reumatoide en un hospital de Sevilla, España. Reumatología Clínica, 2019; 15(5):289-95. 